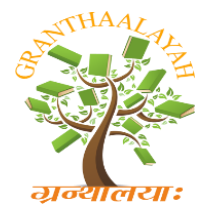

INTERNATIONAL JOURNAL OF RESEARCH GRANTHAALAYAH

A knowledge Repository

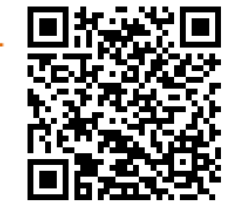

Social

\title{
AGGRESSIVE NATURE OF WOMEN IN THE NOVELS OF ANITA NAIR
}

\author{
T. Pushpanathan *1 \\ ${ }^{* 1}$ Assistant Professor, Department of English, SCSVMV University, Kanchipuram, INDIA
}

\begin{abstract}
This paper seeks to focus primarily on the psychological exploration of inner mind of Indian women in the novels written by an Indian writer in English. There is a need and relevance to dwell briefly on some of the novels of Anita Nair to study the aggressive nature of her women characters and their significance with a view to substantiating this issue. Physical behavior which is threatening or involves harm to someone or something or behaving in an angry and violent way towards another is one sort of aggression.
\end{abstract}

Keywords:

Women characters, aggressive nature.

Cite This Article: T. Pushpanathan, "AGGRESSIVE NATURE OF WOMEN IN THE NOVELS OF ANITA NAIR" International Journal of Research - Granthaalayah, Vol. 4, No. 4 (2016): 64-67.

\section{INTRODUCTION}

Anita Nair describes situations or events in which characters are hurt or killed, because of the aggressive nature of characters in her novels. In the past, men tend to be more aggressive than women. But in the novels of Anita Nair, reality is presented to show how women characters in her novels are aggressive. Women are expressing opinions strongly and demanding attention or action very forcefully. It is an attack on the male dominated society - a sort of dilution they make to weaken their domination.

This paper aims at studying the image of women's aggressive nature at social, familial and financial level. Women are represented as incarnation of Sakthi in legends and great epics, to illustrate her aggressive and assertive nature on the world. Their existence and life in this world is many faceted. She plays the role of a mother, sister, wife, and daughter and there is an extreme kind of domination on social, familial, financial bodies.

A woman is lovable creature of God, to balance man. Naturally, women are physically and mentally weak, because of their staying power. But they suddenly express their feeling and for that she is spoiled during a fight against her counterpart. Anita Nair concerns man, women, 
nature, real life and social convention which explore the inter relationship between man, woman and nature, and between individual man and society. The image of woman is central to the writings of literature all over the world. Women have inspired literature and have themselves been its central theme.

Anita Nair describes how the Indian women are exploited even in the modern times both by individuals and the society and she emphasizes the need for creating awareness in women. Her female protagonists are aware of the injustice meted out to them in marriage. They boldly walk out of their homes when she finds man not fit to be an equal partner; till such partners are ready such women will get weaker in loneliness. She also examines the concept of chastity and the hypocritical attitudes which the Indian society has developed towards aggressive women. Anita Nair shows how her female characters break away from their unhappy martial bonds, taking a strong stand against vital human and familial relationships.

Anita Nair has emerged as a very interesting story- teller through her two novels 'The Better Man' and 'The Ladies' coupe'. Her novels also portray without the least inhibition the complex problems faced by the educated women who lead lives outdoors and large gyno-centric with women protagonists occupying the 'centre' of narrative. They present the problems faced by women who work and live with men in contemporary society. Anita Nair presents women protagonists who find ultimate fulfillment in either martial or in sexuality gratifying men of the choice.

Anita Nair's characters are also liberated, her women seen to liberal where sexuality is concerned, even tending to border on the permissive. But they are all women leading quite healthy lives, capable of making the much-needed adjustments in their personal lives with characteristic realism and intelligence. In short, she summarizes the emerging trends prevalent amongst the urban cream of the crop women who are on the verge of breaking their age-old, custom-venerated shackles of life.

Janaki is one of the characters of 'Ladies' Coupe', gets married to Prabhakar. She has enjoyed forty years of married life. At first, her husband wanted to control everybody. She felt like launching a revolt against him whenever her husband was in a nasty mood. She felt "a queer rage uncoils within her" and bursts out "You just want to control him. You want to control everybody. You want everybody to do your bidding". Janaki takes her husband in her hands, to control him aggressively, because women were weak in the past, strong at present, to restrain man. The modern women control everything and even the family with the help of her strength. Thus, Janaki aggressively controlled her husband and family.

Margaret Shanthi goes through several physical, mental and spiritual crises in life. She keeps on changing till she reaches a state where she feels happy. Her marriage to Ebenezer Paulraj is like a fairy tale wedding. She initially says 'yes' to whatever her husband asks and the he starts controlling her completely. She is forced to do B.Ed. though she wants to do Ph.D. she has to do whatever her husband bids her to. He becomes more and more overbearing after he becomes the principal of the local school. He begins to irritate her and find fault in her housekeeping and cooking. Being a beautiful and pampered wife she was forced to undergo even an abortion which 
she does not like in the least, her being to hate him. So Margaret Shanthi turns her life in a hostile way.

Margaret Shanthi's only consolation in life is food. Suddenly she decides on a cunning method to get her own back from Ebenezer, who loves food and sex, starts pampering him with sex and food so that he becomes fat and lazy. Now he is not able to do any work. Earlier, she had been completely controlled by her husband. Now, he is completely in her hands. She takes him to the hospital for checkups frequently. Margaret's repression can be called one of sexual stereotyping. She is forced to live like a model wife.

Marikolanthu comes from a poor background. Her mother works as a cook at a chettiar household. She is also employed to look after sujata Akka'son. She adores the child and shows much affection while hating her own child Muthu. Muthu is the result of a rape at the hands of Murugesan. The turning point in her life comes very soon, when she sees the dead body of Murugesan burning at a pyre. She sees Muthu she feels shocked at the realization that she feels guilty over her own child. At last she decides to look after him and make up to him for all she had lost. Marikolanthu suffers from an extreme kind of repression, social, familial and financial. Aggressively, she hated that filthy animal, Murugesan.

Prabha Devi's life has been comfortable as a pampered young daughter of a wealthy family. She is married into the rich family of Jagathesh and enjoys her role as a wife and a daughter-in-law. Her trip to New York makes her crave to be like those women with swinging hair and a confident stride. She is very much aware of her physical appearance. She suggests to her husband to use a thin rubber covering because she wants to avoid the pregnancy. She feels that the pregnancy will result in the ruin of her beauty. When she meets Pramod, a friend of her husband she is ready to have sex with him. Pramod goes home thinking her to be "one of those women and she feels jolted out of her artificial world". It is then she completely changes and forgets her beauty and charm and starts enjoying her life with Jagathesh. Even a woman can be ready to face any sort of obstacles that she will face.

Anjana the wife of Ravindran gets introduced to Mukundan. Mukundan suddenly feels that his wife about to blossom to start an affair with Anjana, to start living as husband and wife. Because of Ravindran's impotency, he is unable to give her the conjugal felicity called sex. So she has decided to banish her husband from her life forever and starts to do the divorce proceedings. Having that in mind, she forgives Mukundan's trespasses and accepts him in life. Man's approach towards another woman other than his wife has been justified in real patriarchal. It shows his aggressive nature. Now the women protagonists in her novels take it their right to live, to live happily and when circumstances forbid them, she can go to the extent of violating the so called morality and code of conduct as developed by the same irrational men. Breach of morals is a sort of aggression, to find an identity for her. Women are tending to be more aggressive than usual as they began to give importance to their own self. She has lived for others sacrificing much to be called altruistic. Now she is egocentric to be called aggressive.

Meenakshi is one of characters of Anita Nair, cousin to Mukundan to share her thoughts with him in her youth; they used to be close to each other. As for Meenakshi, she is forbidden to go wandering around the fields with Mukundan. He shall entertain a secret plan to escape. Slowly 
and steadily she begins to fade away from his memory. Meenakshi falls in love with Balan the kathakali dancer; after sometimes. In modern times, a woman has the power to discern and decide upon who her partner should be, ignoring the enticing words of an insincere lover. The woman who makes a better choice walks in the right path.

All these characters assert their individuality after having led difficult lives with men in their aggressive lives. Having gone through the vile way of life they all develop a strong sense of confidence to decide their lives positively or negatively. Their lives prove the fact that women are not weak creatures or pitiable victims but they can achieve everything they need, all by themselves, even without the help of man. But one should impart a role to their conscience.

\section{REFERENCES}

[1] Baskaran, G and Y. Vidya. Native Visions and Alien Voices: Essays on Commonwealth Literature. Virudhunagar: VHN Senthikumara Nadar College, 2011.

[2] Nair, Anita. Ladies coupe. New Delhi: Penguin Books, 2001. Print.

[3] Nair, Anita. Mistress. New Delhi: Penguin Books India, 2005.

[4] Nityanandam, Indira. “A Post-Colonial Reading of Anita Nair's Ladies Coupe..” Indian Writing in English: Perspectives. Ed. Joya Chakravarty. New Delhi: Atlantic Publishers and Distributors, 2003.

[5] Singh, Savita. "Repression, Revolt and Resolution Anita Nair's Ladies Coupe.” The Quest 16.2 (December 2002): 28-35. 